\title{
PROSEDUR PENERIMAAN PASIEN BPJS DI TEMPAT PENDAFTARAN PASIEN RAWAT JALAN
}

\author{
${ }^{1}$ Widya Cahya Permata, \& ${ }^{2}$ Ida Sugiarti \\ 1,2 Jurusan PIKes Poltekkes Kemenkes Tasikmalaya \\ cahyapermatawidya@gmail.com
}

\begin{abstract}
Abstrak
Tujuan penelitian ini untuk meninjau prosedur pelaksanaan penerimaan pasien baru Badan Penyelenggara Jaminan Sosial (BPJS) di pendaftaran rawat jalan. Metode penelitian menggunakan deskriptif dengan pendekatan kwalitatif phenomology dan data yang dikumpulkan dengan teknik triangulasi. Hasil penelitian menunjukkan bahwa 15 pasien baru dari prosedur pendaftaran BPJS ada 3 prosedur tidak konsisten dengan standar prosedur operasional, yaitu prosedur nomor $6,93 \%$ konsisten, nomor 7 , konsisten $10 \%$ dan nomor 8 konsisten hanya $14 \%$. Pendidikan perekam medis terdiri dari SMA 9, SMP 3, D3 Rekam medis 7, D1 Manajemen Rumah Sakit 1, dan S1 teknik elektro 1. Pasien tidak membawa persyaratan lengkap, dalam satu hari komputer dan aplikasi SIMRS terganggu dengan periode yang tidak pasti waktu. SOP pendaftaran rawat jalan baru telah tersedia untuk BPJS, tetapi belum dilaksanakan sepenuhnya. Sumber daya manusia yang cukup dalam kuantitas tapi tidak tepat jika dilihat dari pendidikan terakhir. Fasilitas infrastruktur di pendaftaran rawat jalan perlu ditingkatkan pada antrian mesin dan komputer pendaftaran, dan penambahan mesin antrian. SIMRS aplikasi terhubung ke setiap unit pelayanan tapi kadang-kadang jaringan error.
\end{abstract}

Kata Kunci : tempat pendaftaran rawat jalan, BPJS, Standard Operating Procedures

\begin{abstract}
The purpose this study to review the implementation admissions procedure new patient of Badan Penyelenggara Jaminan Sosial (BPJS) at the outpatient care registration. The research method using descriptive with phenomology approach and data collected with triangulation technique. Research results showed that 15 new patients of BPJS registration procedures there are 3 procedures not consistent with operational standard procedures, that is procedure number $6,93 \%$ consistent, number 7 , consistent $10 \%$ and number 8 consistent only $14 \%$. Medical recorder education background consist of senior high school 9, junior high school 3, D3 Medical Record 7, D1 Hospital Management 1 and S1 technique electro 1. Patients did not carry complete requirements, in one day the computer and the SIMRS application is interrupted with an uncertain period of time. The conclusion a new outpatient registration SOP has been available for BPJS, but it has not been fully implemented. Human resources are sufficient in quantity but not appropriate if seen from the last education. Infrastructure facilities at outpatient registration need to be improved on queuing machine and registration computer, and addition of queue machine. SIMRS application is connected to every service unit but sometimes network error.
\end{abstract}

Keywords :, the outpatient care registration, BPJS, Standard Operational Procedures

\section{PENDAHULUAN}

Tempat penerimaan pasien merupakan gerbang pelayanan pertama di suatu fasilitas pelayanan kesehatan. Pasien memutuskan berobat di fasilitas kesehatan dengan mempertimbangkan tempat penerimaan pasien yang nyaman dan petugas yang memuaskan. Petugas penerimaan pasien harus menguasai alur pasien, terutama alur pasien jaminan Badan Penyelenggara Jaminan Sosial (BPJS) dikarenakan memiliki persyaratan 
yang wajib dipenuhi saat mendaftar berdasarkan Standar Operasional Prosedur (SOP) penerimaan pasien rawat jalan jaminan BPJS.

Menurut Peraturan Menteri

Pendayagunaan Aparatur Negara dan Reformasi Birokrasi Republik Indonesia Nomor 35 Tahun 2012 tentang Pedoman Penyusunan Standar Operasional Prosedur Administrasi Pemerintahan. Standar Operasional Prosedur adalah serangkaian instruksi tertulis yang dibakukan mengenai berbagai proses penyelenggaraan administrasi pemerintahan, bagaiamana dan kapan harus dilakukan, dimana dan oleh siapa dilakukan. Diperlukan pengaturan pencapaian yang baik. Para manager menggunakan sarana atau alat manajemen untuk mencapai suatu tujuan (Alamsyah, 2011).

Penelitian Pujiono (2015), menunjukan pelayanan kesehatan memiliki alur dan prosedur yang harus diketahui dan ditaati oleh pasien khususnya pasien jaminan BPJS rawat jalan. Kelengkapan persyaratan administrasi akan mempengaruhi cepat atau lambatnya proses pelayanan kesehatan. Penelitian Andria dan Sugiarti (2015) menunjukkan ketidaksesuaian alur berdampak pada penyediaan dokumen rekam medis menjadi terlambat. Penelitian Ristya (2015), mengenai kepatuhan petugas TPPRJ dikatakan patuh namun ada beberapa aspek yang belum dilaksanakan karena ada petugas yang memiliki pendidikan yang tidak sesuai, kurangnya mengikuti pelatihan-pelatihan serta pengalaman kerja yang minim berdampak pada pelaksanaan SOP, kecermatan petugas masih kurang teliti dalam melihat perbedaan-perbedaan kecil yang terdapat pada SOP, yang berdampak buruk bagi dokumen pasien sehingga petugas bekerja dua kali untuk memperbaiki kesalahan tersebut sehingga pelayanan pendaftaran belum berjalan dengan maksimal.

Hasil studi pendahuluan menunjukkan masih terdapat ketidaksesuaian proses pelaksanakan pasien rawat jalan jaminan BPJS dengan SOP pendaftaran pasien rawat jalan jaminan BPJS, yaitu terdapat pasien yang belum mengerti alur pendaftaran rawat jalan, sumber daya manusia kesehatan dengan pendidikan yang belum sesuai serta kurangnya pelatihan-pelatihan. Sarana prasarana juga belum memadai dan sistem sering bermasalah. Kegiatan penerimaan pasien rawat jalan tidak sesuai dengan SOP pendafataran. Berdasarkan hal tersebut penelitian melalukan penelitian mengenai bagaimana sarana manajemen yang berkaitan dengan pendaftaran pasien rawat jalan pasien BPJS.

\section{METODE PENELITIAN}

Desain penelitian deskriptif dengan pendekatan kwalitatif phenomology. Teknik pengumpulan data secara triangulasi. Jumlah populasi yaitu 2.308 pasien BPJS, pengambilan sampel dengan rumus Slovin didapatkan 96 pasien dengan teknik pengambilan sampel yaitu accidental sampling. Serta pengambilan informan 5 orang dengan teknik purposive sampling. Instrumen dalam penelitian ini adalah peneliti sendiri, lembar observasi, lembar ceklis, pedoman wawancara, kamera, buku catatan, tape recorder.

\section{HASIL PENELITIAN}

Rawat jalan jaminan BPJS Badan Layanan Umum Daerah Rumah Sakit Umum Kota Banjar belum tersedia Standar Pelayanan Minimal pelayanan pendaftaran pasien baru rawat jalan jaminan BPJS, namun sudah tersedia SOP Pendaftaran Pasien baru Rawat Jalan Jaminan BPJS dengan nomor 445/4717/MKI/2016 yang diterbitkan pada 04 Januari 2016 sebagai pedoman pelaksanaan penerimaan pasien baru jaminan BPJS di pendaftaran rawat jalan, Hasil observasi yang dilakukan terhadap 96 proses pelayanan pendaftaran rawat jalan pasien baru, didapatkan dari 15 tahapan dapat dilihat pada tabel 1. 
Tabel 1. Hasil Observasi Tahapan SOP Pendaftaran Pasien baru rawat jalan jaminan BPJS RSU Kota Banjar

\begin{tabular}{|c|c|c|c|c|c|c|}
\hline \multirow{2}{*}{ No } & \multirow{2}{*}{ Prosedur } & \multirow{2}{*}{ Jumlah } & \multicolumn{2}{|c|}{ Sesuai } & \multicolumn{2}{|c|}{ Tidak Sesua } \\
\hline & & & Jumlah & $\%$ & Jumlah & $\%$ \\
\hline 1. & $\begin{array}{l}\text { Petugas verifikasi rawat jalan menerima } \\
\text { persyaratan pendataran, meliputi Kartu BPJS }\end{array}$ & 96 & $100 \%$ & 0 & $0 \%$ & 96 \\
\hline 2. & $\begin{array}{l}\text { Petugas verifikasi rawat jalan menerima Surat } \\
\text { Rujukan dari Puskesmas atau dokter keluarga }\end{array}$ & 96 & $100 \%$ & 0 & $0 \%$ & 96 \\
\hline 3. & $\begin{array}{l}\text { Petugas verifikasi rawat jalan memeriksa } \\
\text { kelengkapan dokumen pasien. }\end{array}$ & 96 & $100 \%$ & 0 & $0 \%$ & 96 \\
\hline 4. & $\begin{array}{l}\text { Jika persyaratannya sudah lengkap, petugas } \\
\text { verifikasi memeriksa kelengkapan surat rujukan } \\
\text { dari puskesmas. Jika belum lengkap, petugas } \\
\text { verifikasi mempersilahkan pasien melengkapi } \\
\text { persyaratan atau menjadi pasien umum. }\end{array}$ & 96 & $100 \%$ & 0 & $0 \%$ & 96 \\
\hline 5. & $\begin{array}{l}\text { Jika diagnosanya sudah sesuai, petugas } \\
\text { verifikasi mengarahkan pasien untuk mengambil } \\
\text { nomor antrian. Apabila diagnosa dan poliklinik } \\
\text { tidak sesuai, petugas berwenang untuk } \\
\text { mengganti poliklinik tujuan dengan paraf, } \\
\text { kemudian mengarahkan pasien untuk } \\
\text { mengambil nomor antrian }\end{array}$ & 96 & $100 \%$ & 0 & $0 \%$ & 96 \\
\hline 6. & $\begin{array}{l}\text { Petugas pendaftaran memanggil sesuai } \\
\text { nomor antrian pasien }\end{array}$ & 93 & $97 \%$ & 3 & $3 \%$ & 96 \\
\hline 7. & $\begin{array}{l}\text { Petugas pendaftaran mendaftarkan data pasien } \\
\text { BPJS baru tersebut dengan memasukkannya } \\
\text { data pasien ke dalam komputer meliputi : nomor } \\
\text { rekam medis, identitas pasien, nomor peserta } \\
\text { BPJS, tujuan poliklinik }\end{array}$ & 10 & $10 \%$ & 86 & $90 \%$ & 96 \\
\hline 8. & $\begin{array}{l}\text { Petugas pendaftaran mencetak kartu } \\
\text { berobat pasien }\end{array}$ & 13 & $14 \%$ & 83 & $86 \%$ & 96 \\
\hline 9. & $\begin{array}{l}\text { Petugas pendaftaran mencetak Formulir } \\
\text { (Assesment Pasien Rawat Jalan), }\end{array}$ & 96 & $100 \%$ & 0 & $0 \%$ & 96 \\
\hline 10 & $\begin{array}{l}\text { Petugas pendaftaran melengkapi data pasien } \\
\text { baru di rekam medis rawat jalan dan mengisi } \\
\text { kelengkapan Formulir pasien BPJS }\end{array}$ & 96 & $100 \%$ & 0 & $0 \%$ & 96 \\
\hline 11 & $\begin{array}{l}\text { Petugas pendaftaran menyerahkan berkas } \\
\text { rekam medis kepada petugas pembuat jaminan } \\
\text { pasien BPJS }\end{array}$ & 96 & $100 \%$ & 0 & $0 \%$ & 96 \\
\hline 12 & $\begin{array}{l}\text { Petugas pembuat jaminan pasien BPJS } \\
\text { membuat Surat Eligibilitas Peserta (SEP) sesuai } \\
\text { dengan diagnosa dan rujukan dari puskesmas }\end{array}$ & 96 & $100 \%$ & 0 & $0 \%$ & 96 \\
\hline 13 & $\begin{array}{l}\text { Petugas pembuat jaminan pasien BPJS } \\
\text { menyerahkan berkas rekam medis yang sudah } \\
\text { dilengkapi SEP kepada petugas kurir rawat jalan }\end{array}$ & 96 & $100 \%$ & 0 & $0 \%$ & 96 \\
\hline 14 & $\begin{array}{l}\text { Kurir rawat jalan memilah dan menyortir berkas } \\
\text { rekam medis sesuai dengan tujuan poliklinik } \\
\text { untuk disimpan di rak yang sudah disediakan }\end{array}$ & 96 & $100 \%$ & 0 & $0 \%$ & 96 \\
\hline 15 & $\begin{array}{l}\text { Kurir rawat jalan mengantarkan berkas rekam } \\
\text { medis ke setiap poliklinik }\end{array}$ & 91 & $95 \%$ & 5 & $5 \%$ & 96 \\
\hline
\end{tabular}


Ketersediaan Sarana dan Prasarana di Pendaftaran Rawat Jalan. Sarana prasarana yang tersedia di pendaftaran rawat jalan adalah sebagai berikut, terdiri dari 11 meja, 11 kursi, alat tulis kantor tersedia kertas, bolpoin, hekter, isi hekter, namun untuk refil alat tulis kantor kadangkadang tidak tersedia di tempat pendaftaran rawat jalan. Terdapat 6 printer dengan kondisi bagus, 6 komputer dengan kondisi 2 komputer kurang baik, mesin antrian tersedia namun kondisinya rusak sehingga digantikan dengan nomor antrian manual, kartu identitas berobat pasien (KIB) tersedia dengan mesin pencetak KIB yang tersedia di ruang filing rawat jalan, dokumen rekam medis (DRM) pasien baru tersedia di ruang filing rawat jalan.

Ketenagakerjaan Petugas Rekam Medis. Data ketenagakerjaan didapatkan petugas yang berpendidikan SMA 9 orang, SMP 3, D3 Rekam Medis 8 orang, dan S1 Tekhnik Elektro 1 orang.

Ketersediaan Aplikasi SIMRS di Pendaftaran Rawat Jalan. Aplikasi Sistem Informasi Manajemen Rumah Sakit (SIMRS) sudah digunakan dan terhubung dari unit satu ke unit pelayanan lainnya seperti dari pendaftaran rawat jalan terhubung ke poliklinik dan farmasi serta laboratorium, sehingga data pasien yang berkunjung ke rumah sakit sudah terekam dan dapat diakses dengan mudah untuk keperluan pelaporan seperti daftar kunjungan pasien rawat jalan harian, namun dalam pelaksanaan proses pendaftaran kadang-kadang aplikasi tersebut mengalami gangguan seperti jaringan terputus yang mengakibatkan terhambatnya proses registrasi pendaftaran pasien baru rawat jalan BPJS terutama saat pembuatan Surat Eligibilitas Peserta (SEP) bagi pasien peserta jaminan BPJS.

\section{HASIL WAWANCARA}

Tema 1. Ketersediaan pedoman khusus untuk penerimaan pasien baru rawat jalan jaminan BPJS. Tiga informan menyatakan bahwa sudah tersedia pedoman khusus untuk penerimaan pasien baru rawat jalan jaminan BPJS yaitu Standar Operasional Prosedur pendaftaran pasien baru rawat jalan BPJS. Diperkuat dengan pernyataan informan kunci yang menyatakan bahwa belum ada standar pelayanan minimal namun sudah tersedia standar operasional prosedur.

Tema 2. kendala alur penerimaan pasien baru rawat jalan BPJS. Tiga informan menyatakan bahwa kendala yang terjadi yaitu pasien tidak membawa surat rujukan dan kartu BPJS yang belum bayar iuran dapat menghambat pelayanan pendaftaran. Satu informan menyatakan bahwa ada kendala lain yang terjadi yaitu standar operasional prosedur yang tersedia belum sepenuhnya dilaksanakan secara maksimal karena ada urutan prosedur yang masih tertukar urutannya. Pernyataan informan kunci bahwa urutan Standar Operasional Prosedur, urutannya ada yang tertukar, yaitu dilakukan pencetakan SEP terlebih dahulu baru pendaftaran, serta kartu berobat pasien juga tidak selalu dicetak kecuali pasien yang minta.

Tema 3. solusi untuk masalah yang terjadi pada proses pendaftaran pasien baru BPJS. Dua Informan menyatakan solusinya yaitu mengarahkan pasien tersebut untuk membuat terlebih dahulu surat rujukan atau membayar terlebih dahulu iuran BPJS yang belum dibayar. Informan 3 menyampaikan bahwa solusinya adalah setiap petugas pendaftaran baik itu bagian SEP, bagian pendaftaran atau kurir harus lebih teliti dalam bekerja dan meningkatkan kesadaran tanggung jawab dalam bekerja pengambilan kartu harus disusun sesuai poliklinik tujuan dan KIB harus dicetak dan diserahkan ke pasien yang mendaftar. Informan kunci menyampaikan solusi dari kendala yang terjadi yaitu melakukan kegiatan revisi standar operasional prosedur penerimaan pasien baru rawat jalan BPJS setiap 3 tahun sekali dan kartu berobat pasien harus dicetak untuk 
mempermudah pasien pada saat akan berkunjung kembali ke rumah sakit.

Tema 4. Kuantitas sumber daya manusia. Tiga informan menyatakan bahwa secara kuantitas atau jumlah sumber daya manusia yang ada di tempat pendaftaran pasien rawat jalan sudah memadai.

Tema 5. kendala mengenai sarana dan prasana yang digunakan di tempat pendaftaran Pasien rawat jalan. Tiga informan menyatakan untuk sarana prasarana masih ada kendala, yaitu mesin nomor antrian error, komputer bagian SEP kadang - kadang error, kertas serta isi hekter tidak tersedia refilnya.

Tema 6. Masalah aplikasi SIMRS yang digunakan di tempat pendaftaran pasien rawat jalan terkadang error. Keempat informan menyatakan bahwa aplikasi SIMRS kadang-kadang mengalami eror atau jaringan BPJS yang terputus serta komputer billing juga terkadang error. Diperkuat dengan pernyatan dari informan kunci, bahwa aplikasi SIMRS kadangkadang mengalami gangguan yang menimbulkan dampak buruk pada proses pelayanan pendaftaran pasien rawat jalan BPJS.

Tema 7. dampak dan solusi mengenai kendala aplikasi SIMRS. Keempat informan menyatakan bahwa dampak dari kendala tersebut yaitu menghambat proses pelayanan registrasi serta mengakibatkan penumpukan berkas dan solusinya yaitu memanggil petugas IT untuk segera diperbaiki atau mendaftarkan dahulu baru kemudian cetak SEP atau di tulis secara manual dan dilakukan penginputan data pasien setelah jaringan pulih kembali. Diperkuat dengan pernyataan informan kunci bahwa aplikasi SEP dan computer billing eror maka akan menghambat pelayanan

\section{PEMBAHASAN}

Berdasarkan hasil observasi dan wawancara, dalam proses pelayanan pendaftaran pasien baru jaminan BPJS di tempat pendaftaran pasien rawat jalan RSU Kota Banjar belum mengacu terhadap standar pelayanan minimal rumah sakit yang di tetapkan dalam Keputusan Menteri Kesehatan Nomor 129 tahun 2009 tentang Standar Pelayanan Minimal Rumah Sakit. RSU Kota Banjar sudah tersedia Standar Operasional Prosedur pendaftaran pasien baru rawat jalan jaminan BPJS dengan nomor dokumen 445/4717/MKI///2016 dengan tahun terbit 4 Januari 2016. Menurut Peraturan Menteri Pendayagunaan Aparatur Negara dan Reformasi Birokrasi Republik Indonesia Nomor 35 tahun 2012 tentang Pedoman Penyusunan Standar Operasional Prosedur Administrasi Pemerintah, Standar Operasional Prosedur pendaftaran pasien baru rawat jalan jaminan BPJS, termasuk jenis SOP teknis, karena pelaksanannya dalam kesatuan tim dan berisi langkahlangkah rinci dalam pelaksanaan kegiatan. Dalam pelaksanaan masih ada 3 tahapan dalam prosedur tersebut yang belum dilaksanakan secara maksimal. Hal ini kemudian dikonfirmasi kepada informan kunci, didapatkan bahwa untuk prosedur nomor 6 masih ada 3 yang belum sesuai itu dilakukan ketika nomor antrian kosong atau tidak penuh maka pasien dapat langsung mendaftar. Nomor 7 sebaiknya dibuatkan pembuatan SEP dahulu supaya terlihat jenis pasien BPJS PBI dan non PBI atau pengecekan kartu BPJS apakah masih aktif atau belum bayar iuran bisa terlihat kemudian dilakukan pendaftaran ke bagian billing sehingga pendaftaran lebih efektif dan efisien, kemudian untuk permasalahan nomor 8 itu memang tidak selalu dicetak kartu berobat karena selalu hilang pada saat didistribusikan menuju poliklinik yang dituju. Hal ini tidak sesuai karena menurut Depkes (2007) karena, setiap pasien baru yang diterima di pendaftaran rawat jalan akan memperoleh kartu identitas berobat yang harus dibawa setiap kembali berkunjung baik sebagai pasien rawat jalan maupun sebagai pasien rawat inap, jika tidak akan timbul masalah 
lainnya seperti terjadi duplikat kartu berobat atau nomor rekam medis.

Hambatan lainnya berdasarkan hasil wawancara dengan ke empat informan dan informan kunci yaitu pasien baru yang tidak membawa persyaratan lengkap seperti surat rujukan dan kartu BPJS nya belum bayar iuran, akan menghambat proses pelayanan pendaftaran. Karena menurut Peraturan Menteri Kesehatan Republik Indonesia Nomor 28 Tahun 2014 tentang pdoman pelaksanaan program JKN bahwa peserta datang ke rumah sakit dengan menunjukan nomor identitas peserta JKN dan surat rujukan kemudian akan mendapat surat eligibilitas peserta dan akan memperoleh pelayanan rawat jalan atau rawat inap.

Berdasarkan hasil wawancara dan observasi mengenai kuantitas atau jumlah petugas pendaftaran sudah cukup memadai namun menurut informan kunci akan lebih baik jika dilakukan penambahan jumlah petugas dengan latar pendidikan D3 Rekam Medis, dan kurangnya pelatihan- pelatihan terkait rekam medis. Hal tersebut belum dikatakan baik, karena menjalakan pekerjaan di unit rekam medis diperlukan sumber daya manusia yang memenuhi kompetensi perekam medis. Pentingnya penguasaan kompetensi untuk seorang profesional perekam medis terkait dengan kualitas kerja dan jenjang karirnya di unit rekam medis, tuntutan kompetensi tersebut diimbangi dengan adanya Kepmen Pendayagunaan Aparatur Negara Nomor 377 tahun 2007 tentang Standar Profesi Perekam Medis dan Informasi Kesehatan, yaitu tugas pokok perekam medis adalah melaksanakan pelayanan rekam medis. Seorang perekam medis hendaknya mengikuti pelatihan secara kontinyu untuk meningkatkan kompetensi yang dimiliki.

Aplikasi SIMRS yang digunakan sudah terhubung ke setiap poliklinik yang dituju serta terhubung ke bagian farmasi. Adanaya SIMRS, petugas pendaftaran bisa mengakses data atau bisa dengan mudah mencari data yang diperlukan misalnya jumlah data kunjungan perhari pasien BPJS, sehingga memudahkan pelayanan karena perawat atau dokter dapat melayani pasien sesuai dengan nomor urutan pasien yang mendaftar ke masing-masing poliklinik. Sesuai dengan Permenkes RI Nomor 82 tahun 2013 tentang Sistem Informasi Manajemen Rumah Sakit, bahwa Sistem Informasi Manajemen Rumah Sakit (SIMRS) adalah suatu sistem teknologi Informasi komunikasi yang memproses dan mengintregasikan seluruh alur proses pelayanan rumah sakit dalam bentuk jaringan koordinasi, pelaporan dan prosedur adminitrasi untuk memperoleh Informasi secara tepat, cepat dan akurat.

\section{KESIMPULAN}

Sudah tersedia pedoman untuk alur prosedur pendaftaran pasien baru jaminan BPJS di tempat pendaftaran pasien rawat jalan, namun dari 15 tahapan di prosedur tersebut masih ada 3 tahapan yang belum dilaksanakan sesuai dengan pedoman tersebut.

Sumber daya manusia kesehatan yang bertugas sudah memadai secara kuantitas, namun belum sesuai bila dilihat dari pendidikan terakhir.

Sarana prasarana cukup memadai, namun masih ada kendala yaitu kondisi sarana yang kurang baik, komputer SEP dan komputer billing kadang-kadang mengalami gangguan, mesin nomor antrian rusak, belum tersedia alat pemanggil antrian otomatis di pendaftaran rawat jalan serta refill alat tulis kantor.

Sistem Informasi Manajemen Rumah Sakit (SIMRS) sudah digunakan namun masih ada kekurangan yaitu aplikasi pembuatan SEP terkadang mengalami putus jaringan, dan aplikasi billing pun sama mengalami error

\section{SARAN}

Perlunya diadakan sosialisasi dan pelatihan mengenai pelaksanaan isi Standar Operasional Prosedur (SOP) 
pendaftaran pasien baru rawat jalan jaminan BPJS untuk menambah pengetahuan dan meningkatkan keterampilan petugas pendaftaran rawat jalan.

Perlunya dilakukan evaluasi mengenai kesesuaian pelaksanaan antara kondisi di lapangan dengan isi standar prosedur operasional yang ada, bila perlu revisi SOP.

Perlu dilakukan pemberian informasi kepada pasien, mengenai alur pendaftaran pasien BPJS di tempat pendaftaran pasien rawat jalan dalam bentuk flowchart.

Perbaikan dan penambahan sarana dan pra sarana serta perbaikan jaringan atau pergantian jaringan secara berkala.

\section{DAFTAR PUSTAKA}

Afiyanti, Y., Rachmawati, I. (2014),

Metodologi Penelitian Kualitatif Dalam

Riset Keperawatan. Jakarta: PT

RajaGrafindo Persada

Alamsyah, D., (2011), Manajemen

Pelayanan Kesehatan. Yogyakarta :

Nuha Medika.

Andria, Firzah D., \& Sugiarti, I., (2015)

Tinjauan Penyediaan Dokumen

Rekam Medis di RSUD Dr. Soekardjo

Kota Tasikmalaya, Jurnal Manajemen

Informasi Kesehatan Indonesia Vol. 3

No. 2, Oktober 2015, ISSN : 2337-

6007.http://jmiki.aptirmik.or.id/index.ph p/jmiki/article/view/85

Arikunto, S., (2010). Prosedur Penelitian Suatu Pendekatan Praktik. Jakarta : Rineka Cipta.

Budi,S.C., (2011). Manajemen Unit Kerja Rekam Medis. Yogyakarta : Quantum Sinergi Media.
Depkes, RI., (2006) . Pedoman

Penyelenggaraan dan Prosdur Rekam

Medis Rumah Sakit di Indonesia

Revisi II. Jakarta : Depkes RI.

Emzir, (2012), Metodologi Penelitian

Kualitatif Analisis Data. Jakarta:

Rajawali Press

Hatta, G., (2013), Pedoman Manajemen Informasi Kesehatan di Sarana Pelayanan Kesehatan Edisi Revisi 2. Jakarta: UI Press

Notoatmodjo, S.D., (2010) Metodologi Penelitian Kesehatan. Jakarta : Rineka Cipta

Pujiono, Agus dan Eti Rimawati. 2015. Jurnal Pengetahuan Peserta BPJS tentang Alur Prosedur Pelayanan Pasien Rawat Jalan RSUP Dr Kariadi Semarang

Ristya, P., dan Kurniadi, A., (2015), Kepatuhan Petugas TPPRJ dalam Pelaksanaan Standar Prosedur Operasional Pendaftaran Pasien BPJS di Rs Pantiwilasa Dr.Cipto Kota Semarang Tahun 2015. http:// eprints.dinus.ac.id/17487/1/jurnal1643 7.pd

Rustianto, E., (2009). "Etika Profesi : Perekam Medis Informasi Kesehatan", Yogyakarta.

Sugiyono, (2012), Metode Penelitian Kuantitatif Kualitatif dan R\&D. Bandung: Alfabeta.

Sujarweni, V.W., (2014) Metodologi Penelitian: lengkap, praktis dan mudah Dipahami. Yogyakarta: Pustaka Baru Press. 